\title{
Linking Up: The Role of Institutions and Farmers in Forage Seed Exchange Networks of Southeast Asia
}

\author{
James D. Leyte ${ }^{1} \cdot$ Erik Delaquis $^{2}$ (D) - Pham Van Dung ${ }^{3} \cdot$ Sabine Douxchamps ${ }^{3}$ (i)
}

Accepted: 1 October 2021 / Published online: 16 October 2021

(c) The Author(s) 2021

\begin{abstract}
In Southeast Asia, access to improved forages remains a challenge for smallholder farmers and limits livestock production. We compared seed exchange networks supporting two contrasting livestock production systems to identify bottlenecks in seed availability and determine the influences of the market, institutions, and cultural context of seed exchange, using interview-based methods for 'seed tracing' and network analysis. Government agencies were the primary sources of high-quality genetic materials, with secondary diffusion in the Philippines dairy case being dominated by key individuals in active cooperatives. In the Vietnamese beef-oriented production context, farmer to farmer dissemination was more substantial. In both cases, formal actors dominated where botanical seed was exchanged, while farmers frequently exchanged vegetatively propagated materials among themselves. To improve access to forage seed in these contexts, government agencies and development actors should coordinate quality seed production upstream while supporting the creation of appropriate training, structures, and incentives for seed exchange network improvement downstream.
\end{abstract}

Keywords Genetic resources $\cdot$ Informal seed system $\cdot$ Social network analysis $\cdot$ Vietnam $\cdot$ Philippines

\section{Introduction}

\section{Forages Dissemination in Southeast Asia}

Demand for beef and milk increases globally and is expected to double by 2050 due to a growing middle class (Rao et al., 2015). In Southeast Asia, the rapid pace of this transformation is putting pressure on livestock production systems. Most of the meat and milk produced in the developing world come from mixed crop-livestock systems (Herrero et al., 2010), primarily small in scale in the Southeast Asian context. The most important factors limiting production for these systems are feed availability and quality (Rao et al., 2015). Each year, millions of tons of feed are currently imported by Southeast Asian nations, despite the potential

Sabine Douxchamps

s.douxchamps@cgiar.org

1 International Center for Tropical Agriculture (CIAT), Tropical Forages Program, Los Baños, Philippines

2 International Center for Tropical Agriculture (CIAT), Cassava Program, Vientiane, Lao PDR

3 International Center for Tropical Agriculture (CIAT), Tropical Forages Program, Hanoi, Vietnam economic and environmental advantages of local production, especially in remote areas (Stür et al., 2002). High-quality, protein-rich forages can increase the quantity and quality of meat and milk and produce a range of environmental benefits (Rao et al., 2015).

Starting 30 years ago, the International Center for Tropical Agriculture (CIAT) has conducted adaptive research to identify suitable forage germplasm providing solutions to smallholder farmers in Southeast Asia. Through a series of research projects spanning this period (Table 1), more than 500 forage species have been introduced and evaluated in nurseries. Selected species were tested in participatory trials and multiplied by farmers (Stür et al., 2002).

These efforts ultimately reached more than 10,000 households in Southeast Asia (Roothaert et al., 2003; Stür et al., 2006). Documented benefits included labor savings of $3 \mathrm{~h}$ per day for Vietnamese farmers who produced feed from Paspalum atratum 'BRA 9610' and Panicum maximum 'T58,' and high-quality forage production paired with erosion prevention for farmers in the Philippines who planted Setaria sphacelata var. sphacelata in contour lines on steep slopes.

Preferred species emerging from this work included high-performing legumes such as Stylosanthes guianensis 
Table 1 Major CIAT forage improvement programs in Southeast Asia

\begin{tabular}{|c|c|c|c|}
\hline Project title & Acronym & $\begin{array}{l}\text { Implementation } \\
\text { period }\end{array}$ & Locations \\
\hline Forage for smallholder projects & FSPs & 1992-2002 & $\begin{array}{l}\text { Indonesia, Malaysia, Philippines, } \\
\text { Thailand, Vietnam, China } \\
\text { (Hainan), Lao PDR, }\end{array}$ \\
\hline $\begin{array}{l}\text { Enhancing livelihoods of poor livestock keepers through increased use of } \\
\text { fodder }\end{array}$ & FAP & 2008-2011 & Ethiopia, Syria, Vietnam \\
\hline Livelihood and Livestock Systems Project & LLSP & $2003-2005$ & $\begin{array}{l}\text { Cambodia, China, Indonesia, Lao } \\
\text { PDR, the Philippines, Thailand, } \\
\text { Vietnam }\end{array}$ \\
\hline Forage legumes for supplementing village pigs in Lao PDR & L4PP & $2006-2008$ & Lao PDR \\
\hline One health smallholder pig systems & SPSP & 2010-2015 & \\
\hline $\begin{array}{l}\text { Improved forage-based livestock feeding systems for smallholder livelihoods } \\
\text { in the Cambodia-Laos-Vietnam Development Triangle }\end{array}$ & CLVLP & 2011-2015 & Cambodia, Lao PDR, Vietnam \\
\hline
\end{tabular}

'Stylo CIAT184' and Leucaena leucocephala, grasses such as Panicum maximum, Pennisetum purpureum, Brachiaria humidicola, Brachiaria brizantha, and Brachiaria hybrids such as the well-adopted 'Mulato' and 'Mulato II'. In the period following these interventions, introduced forages have continued to spread beyond the boundaries of the original participant groups. It is not unusual to find examples in government or NGO-run demonstration plots far from the original intervention areas. In addition to farmer adoption, government extension services have likewise integrated new forages into their demonstration trials, participatory research agendas, and country-level dissemination strategies.

Notably, a significant outcome of tropical forage research projects in the region was the creation of a smallholder seed production program led by Ubon Ratchathani University in Thailand, which later launched Ubon Forage Seeds Co., Ltd., the first premium producer of tropical forage seeds in Southeast Asia (https://www.ubonforageseeds.com/en/, and Hare et al., 2013). Further initiatives have sprouted at the national level, with the most notable adoption rates reported in the Philippines and Vietnam (Bosma et al., 2003; Stür et al., 2006; Ayele et al., 2012).

However, despite these immediate successes, long-term adoption of improved forages remains limited, with seed availability and accessibility a common factor (Phaikaew \& Stür, 1998; Philp et al., 2019). Identified reasons for these gaps involve the critical competition for the land area between forages, food, and industrial crops, a lack of policy support to stimulate local forage production, and a lack of community participation in research and development processes (Elbasha et al., 1999; Schultze-Kraft \& Peters, 1997; Thomas \& Sumberg, 1995). Despite the importance of improved forages to livestock holders, little research has since been published evaluating the seed systems of forage crops relative to those of food crops in Southeast Asia, despite longstanding calls for increased efforts (Phaikaew \& Stür, 1998). A particularly glaring gap is apparent in the lack of study of ongoing scaling of forage introductions, including post-project implementation, through farmer networks. One potential reason is the historical development focus on promoting intensification of livestock systems and the associated development of forage technologies 'on-station' for transfer to farmers organized in commercial or projectbased groups, rather than co-generation of local, contextual production strategies for forage seed (Stür et al., 2002). This optimistic model of 'hand over' of technologies has slowly given way to recognition of the more complex nature of challenges in collective action in seed systems (Tadesse et al., 2019), as in other themes such as citizen science (Leeuwis et al., 2018).

\section{Seed Systems: Conceptualization and Role of the Institutions}

Conceptually, seed systems encompass all aspects of the production, maintenance, storage, and diffusion of plant propagules (Tripp, 1997a). In addition to this processbased definition, a stakeholder-based definition is provided by Bentley et al. (2018) to describe seed systems vis-à-vis the producers, users, researchers, policymakers, sellers, and all other participants in the production, distribution, and use of seed of given crops in a given area. Within both of these definitions (and much of the literature at large), the term 'seed' is employed to include all reproductive materials, including 'true' or botanical seed, as well as vegetative reproductive materials such as cuttings, rhizomes, or grafting materials (e.g., Abizaid et al., 2016). Understanding the context-specific structure and functioning of seed systems is important for ensuring seed security (McGuire \& Sperling, 2013), preserving local agrobiodiversity (Pautasso et al., 2013), impeding the spread of pests and diseases (Gitaitis \& Walcott, 2007; Jacobsen et al., 2019; McQuaid et al., 2016), and reaching producers with technologies such as improved 
varieties with enhanced agronomic characteristics (David \& Sperling, 1999; Gaffney et al., 2016).

Seed systems are often categorized in practice in terms of either informal / farmer networks (eg. saving of own seed, exchange among acquaintances), and formal/institutional networks (eg. government or licensed private sector multiplication of quality-controlled seed); of these two, the former is vastly dominant, accounting for perhaps $90 \%$ of seed supply globally (McGuire \& Sperling, 2016), and is of even greater importance in developing country contexts (Almekinders et al., 1994; Gill et al., 2013; Louwaars \& de Boef, 2012). Informal seed systems are increasingly undergoing an image shift from disorganized, chaotic purveyors of the seed of unknown origin to dynamic adaptive systems that efficiently reach large producers with planting materials acceptable to them (Coomes et al., 2015). However, formal seed systems often have advantages in accessing and introducing novel seeds and genetic materials through sources such as international seed companies, government breeding programs, or mechanisms such as gene banks and the multilateral system of the Plant Treaty. They are often instrumental in exchanges crossing administrative borders. The formal/ informal dichotomy, although sometimes helpful in discussing seed systems, belies a more complex reality of a heterogeneous stakeholder and exchange landscape defying simple binary categorization. In practice, seed systems are mixed, with informal and formal actors interacting, and commercial transactions often playing a more prominent role than previously believed (Delaquis et al., 2018; McGuire, 2008).

Decentralization and increased private sector involvement have been increasingly promoted as strategies for increasing smallholder seed access (Almekinders et al., 2019), implying the existence of formal or semi-formal structures for seed introduction to serve as entry points for broader dissemination through informal networks. For such models to effectively benefit large numbers of producers, formal or semi-formal systems must link with social networks for secondary and tertiary exchange (Tadesse et al., 2017). Thus, the interface of formal and informal networks through institutional networks plays a critical role in scaling seed exchange, especially the interactions between groups or institutions providing access to seed resources. The degree to which institutional networks foster seed exchange both within and outside of the group. However, empirical evidence supporting the effectiveness of these models is limited outside of a few major cash crops (Tadesse et al., 2019).

In this study, we employ a conceptualization of seed systems based on the work of the CGIAR Research Program on Roots, Tubers and Bananas, a community of over 50 seed system researchers focusing on the seed systems of vegetatively propagated crops. Building on dozens of case studies, the group has produced a toolbox for working with seed systems, including a method for 'seed tracing' studies, in which seed exchange transactions are mapped between stakeholders (Andrade-Piedra et al., 2020). We focus on exchange networks as a middle segment of the seed value chain, bridging upstream breeding and selection and downstream use to produce animal feed. Within this segment of the seed value chain we adapt the conceptual model for seed diversity of Stromberg et al. (2010), considering the forage seed exchange network as embedded in a larger cultural context comprised of 3 major mediating factors: collective action and institutions, market integration, and cultural norms that shape seed exchange practices.

\section{Networks and Seed Tracing}

Network analysis has been developed as a method for comparative analysis of seed exchange networks (Abizaid et al., 2016; Delaquis et al., 2018; Tadesse et al., 2017), generating insights into the impacts of planting material introductions, conservation of agrobiodiversity, and identifying pathways to greater varietal adoption. Interview-based methods for seed tracing have been helpful as a method for rapid evaluation of seed exchange networks, the impacts of seed interventions through secondary exchange after project-based interventions (Almekinders et al., 2020), and for constructing networks for epidemiological modeling (Buddenhagen et al., 2017; Garrett et al., 2018). These methods generate visualization and statistical evidence of stakeholder exchange patterns, allowing for identifying key actors and their roles and positions in the network. Measures such as degree centrality and emergent properties such as network flatness provide comparability relevant to understanding the functioning of networks as a whole in addition to the characteristics of constituent stakeholders.

To evaluate the impact of collective action and institutions, market integration, and cultural norms on forage exchange patterns within and beyond established farmer groups, this study evaluates two contrasting representative livestock production systems in Southeast Asia through survey-based assessments in selected sites to (i) characterize the forage seed exchange network structure beginning with producers' groups (members' roles, functioning and delivery of different types of seed), (ii) compare critical characteristics of identified seed networks and contextual elements, and (iii) to evaluate the role of institutions in forage seed dissemination between the members and in the interface with informal networks.

The two contrasting livestock production systems evaluated were a specialized dairy system based around several smallholder cooperatives with high market access in the Philippines and a diverse smallholder crop-livestock beef production system under a government-organized producers' group with low market access in Northern Vietnam. We hypothesize that seed exchange behavior and networks will 
fundamentally differ between farmers' organization types, leading to different institutional roles in seed networks and differences in exchange patterns and types beyond group members due to different market, institutional, and cultural norm contexts.

\section{Materials and Methods}

\section{Forage and Livelihood Case Study Selection in the Philippines and Vietnam}

The Philippines and Vietnam have recently been upgraded to lower-middle-income country status (WB, 2020a), have comparable levels of development, and have rapid average growth rates (WB, 2020b and 2020c). As described above, the countries share a common history of forage dissemination efforts and comparable short-term successes, with rapidly developing livestock sectors and increasing demand for forages. However, the case studies differed in market orientation and group organization, with dairy cooperatives with strong collective action in the Philippines versus more individual farmers in Vietnam, organized in government-defined producers' groups. These two cases were selected for their representation of dominant livestock production strategies in Southeast Asia for the dairy and the beef sector, respectively.

The Philippines produces 1\% of the national demand for dairy, importing the remainder from the US, Australia, and New Zealand (Ang, 2017; PSA, 2016). Although the dairy sector has seen positive growth over the past decade with increased private investment, most production still originates from smallholder crop-livestock farms. The most common practice of feeding dairy cows is through the cut-and-carry method, in which forages are planted in a separate lot and harvested as needed. Availability of planting materials of improved forages is a major production constraint. While indigenous forages and crop residues were traditionally sufficient for low-density small-frame native animals, dairy cattle need additional feed to maintain profitable milk yields. This gap can be filled with commercial feed or cheap and readily available residues like maize silage. However, the former is expensive, while the latter struggles to meet the protein requirements for quality dairy production. Philippine dairy farmers are organized in cooperatives prioritized by government projects mandated to distribute high-quality forage planting materials, evaluated on the farm by farmers, and exchanged among community members.

In 2014, the Philippines New Zealand Dairy Project collaborated with the National Dairy Authority (NDA) to introduce improved forage varieties suited to Philippine conditions, such as Mulato II (Brachiaria hybrid) and Mombasa (Panicum maximum), in the provinces south of
Manila. Since then, dairy cooperatives in the project area of Quezon, Laguna, and Batangas provinces have been integrating cut and carry of improved forage varieties to supplement managed grazing. These provinces are part of the Philippine dairy belt, but the minimal effort has been made to understand how seed moves within and outside project beneficiary groups.

In Vietnam, livestock production is one of the fastestgrowing agricultural sub-sectors and is concentrated in three geographical regions, including the Northern Mountains, the Central Coast, and the Central Highlands. Son La province is significant in the Northern region because of its large animal population and land resources for grazing and forage production. Implementing government resolution 258/2008 on the development of large cattle and ruminants resulted in a significant increase in dedicated forage area in Son $\mathrm{La}$ between 2009 and 2015. In Mai Son district, this policy resulted in the cultivation of over 321 hectares of forage and animal feed crops (Sub-department of Agriculture and Rural Development Mai Son, 2018). Well-adapted forages recommended for this region include Elephant grass (Pennisetum purpureum), Ruzi grass (Brachiara ruziziensis), TD58 grass (Panicum maximum cv. TD58), Guinea grass (Panicum maximum Jacq.), and VA06 (Pennisetum purpureum cv. VA06). However, growing forages is not a traditional activity for most smallholder farmers. Bovids are mainly used for labor, transport, and beef production and are part of diverse crop-livestock systems. Plots dedicated to cut-andcarry forage production remain limited in comparison to the number of cattle and buffalos. Common feed strategies for cattle and buffalo include the use of maize, sorghum, and other crop residues and free grazing on pasture, fallow land, and grassy roadsides.

\section{Selected Study Sites}

In the Philippines, the study was carried out in four dairy cooperative communities located in the dairy mentioned above belt close to Manila: Palasan Dairy MultiPurpose Cooperative (PALCON) in Quezon province, Samahang Maggagatas ng Batangas Cooperative (SAMABACO) in Batangas province, and San Pablo Dairy Cooperative (SAPADACO) and SALBA Dairy Multipurpose Cooperative (SALBA) in Laguna province (Fig. 1). The region is relatively flat and includes coastal areas and highlands. Manila Bay borders it in the west and is approximately $75 \mathrm{~km}$ to Metro Manila in the north. It has two pronounced seasons: relatively dry from November to April and wet from May to October. The region is predominantly agricultural, and market-oriented dairy production is one of the leading agricultural activities. 


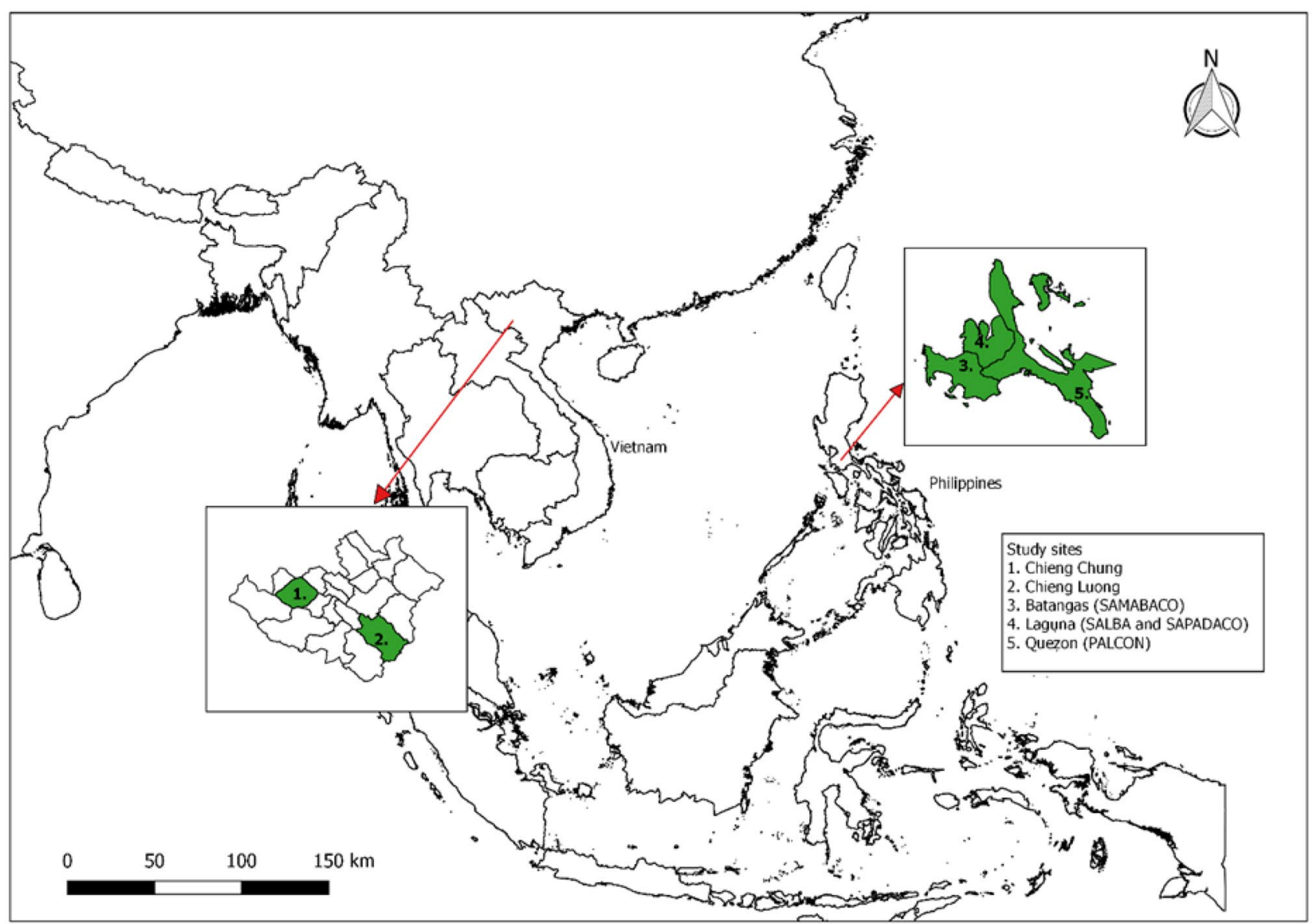

Fig. 1 Map of Southeast Asia highlighting the study areas

In Vietnam, the study was carried out in two communes of Mai Son district, Son La Province: Chieng Chung and Chieng Luong (Fig. 1). The area is mountainous, with steep slopes prone to soil erosion. The two communes are inhabited chiefly by ethnic minorities (Thai and Hmong) and are remote from regional markets (around $50 \mathrm{~km}$ in mountainous terrain). Provincial poverty rates are among the highest in the country (WB, 2018), reaching $11.5 \%$ and $17.8 \%$ in Chieng Chung and Chieng Luong, respectively (Dinh Thanh, 2020). Farming is still partially subsistence-oriented, with diverse agricultural production; field crops include rice, sugarcane, maize, and fruit trees, while livestock species include cattle, goats, pigs, and poultry. Feeding systems generally differed according to landscape position: hilltops with more accessible grazing areas, mid-slope zones offer more maize and sorghum crop residues, and low-lying lands are primarily paddy areas with rice residues. Farmers were not organized into commercial cooperatives as in the Philippine case, but rather in communal farmers' unions by the state, engaged in sharing information, training, and less commonly group purchasing/selling or access to material support for agricultural activities.

\section{Seed System Survey}

Farmer and key stakeholder interviews were carried out from June-October 2019 in the Philippines and September-October 2019 in Vietnam. The questionnaire used in both countries was adapted from Delaquis et al. (2018), and aimed at capturing general socio-demographic information, description of forage seed use, and seed exchange behaviors. Respondents were asked to list the forage varieties on their farm, seed sources, and seed exchange partners over the past five years. Additional information was gathered for each forage seed transaction, including planting material species and reproductive type (true seed or vegetative). The transactions were classified into four categories: 'gathered' (self-produced or collected from community areas), 'gift' from relatives or friends, 'purchased', or 'distributed' by government or projects. Social relationships involved in each transaction were collected, reflecting the interviewee's classification (relative vs. neighbor, for example).

The sampling strategy and the sampling boundaries were defined similarly for both cases through consultations with national government agencies and using a seed tracing 
methodology adapted from Kilwinger and Buddenhagen (2021). In the Philippines, NDA and the University of the Philippines Los Baños Dairy Training Research Institute (UPLB-DTRI) recommended individual farmers and government personnel in four dairy-producing communities. The selected farmers were adopters and beneficiaries of forage materials and participants in varietal trials, while government personnel conducted capacity building and extension work. These focal nodes served as entry points for a snowball sampling technique interviewing actors that had seed transactions with the first group. The network population had a total of 30 identified actors, among which 20 were surveyed. Snowball sampling continued for a second round, while nodes at the third-degree level were not interviewed but were included in network mapping.

In Vietnam, initial scoping meetings were conducted with local agencies (the Mai Son Agricultural Service Center and the Sub-Department of Agriculture and Rural Development) and critical traders to gain insights into forage seed distribution networks and local forage projects and local government involvement before survey implementation. In each of the two selected communes, six farmers involved with cattle production were selected for each landscape position (lowlands, middle slopes, and hilltops). The sampling procedure followed the method used in the Philippines, with subsequent snowball sampling identifying 25 farmers.

\section{Seed Exchange Network Analysis}

Seed exchange network analysis was conducted using the package 'igraph' in R version 3.6.3 (Csardi \& Nepusz, 2006). Stakeholders were coded as nodes and transactions between actors as links. Simple network properties were calculated as described by Shaw and Pautasso (2014). To compare the relative positions of actors in each network, two descriptive metrics were computed for all node positions: degree centrality and betweenness centrality.

Degree centrality measures the direct connectedness of individual nodes with other nodes in the network. It can be calculated as:

$C_{D}\left(n_{i}\right)=d\left(n_{i}\right)=\sum x_{g-1}$

where $C_{D}\left(n_{i}\right)$ is the degree centrality, $d\left(n_{i}\right)$ is the number of nodes connections, and $\sum x_{g-1}$ is the sum of all other nodes in connection. The nodes with the highest degree of centrality are sometimes called 'nodal' actors in the network (Wasserman \& Faust, 1994). For directed graphs, in- and out-degree scores measure the number of links that point toward or away from a given node, respectively, in a directional network graph.

Betweenness centrality measures the number of times a node lies on the shortest path between all other sets of nodes (Scott, 2004) and is calculated as.

$$
C_{B}\left(n_{i}\right)=\sum_{j<k} \frac{g_{j k}\left(n_{i}\right)}{g_{j k}}
$$

where $C_{B}\left(n_{i}\right)$ is betweenness centrality, $g_{j k}$ the number of connections between node $j$ and $k$, and $g_{j k}\left(n_{i}\right) / g_{j k}$ the estimated probability that this path will be chosen. The betweenness centrality index for nodes $n i$ is given as the sum of these estimated probabilities over all pairs of nodes excluding $i$ th nodes.

Betweenness centrality indicates the influence of an actor in facilitating flow between different areas of the network. Hence, nodes with relatively higher betweenness scores are termed as 'connector' nodes in the network. Connector nodes influence integration between the core and the periphery of the network and between otherwise distant actors. Therefore, removing these nodes from the network (for example, the migration of a given farmer or the closing of a seed company) would have powerful effects on the integrity of the network (Poudel et al., 2015).

\section{Results}

\section{Farmer Characteristics and Forage Species}

Farmers and system characteristics differed between the Philippines and the Vietnam sites (Table 2). Farmers in the Vietnam sites were younger than in the Philippines, and on average, had fewer bovine holdings and smaller dedicated forage areas. In both sites, farmers also raised other livestock species, including poultry and pigs. The Philippines' average total livestock units (TLU) was higher than Vietnam due to the former's higher holdings of dairy cows. The Philippine site had a household average of 33 dairy cows, 1 pig, and 7 chickens, while in Vietnam, households had average holdings of 3 beef cattle, 7 pigs, 82 chickens, and 27 ducks. All farmers in the Philippine survey were members of one of the farmer cooperatives, and in Vietnam, farmers were members of communal unions. In the Philippines, milk sales were the primary source of income for all farmers, complemented in a few cases by remittances and off-farm employment. In Vietnam, sources of income were more diverse, with dependence on crop and livestock sales (up to $60 \%$ of the production is sold) and essential sources of off-farm employment.

Forage listed species were more diverse in the Philippines than in Vietnam, with 18 versus 4 species mentioned (Table 3). Napier grass (Pennisetum purpureum) dominated forage use in the Vietnam site, with only a single farmer using each of Mulato II and Mombasa. Mulato II was most widely adopted in the Philippines sites, followed by Mombasa and Napier, and thirteen farmers diversified forage grasses with legumes and shrubs. 
Table 2 Farmers and systems characteristics in the Philippines and Vietnam sites

\begin{tabular}{llll}
\hline Characteristics $^{1}$ & Units & Philippines & Vietnam \\
\hline System type & - & Market oriented dairy & Subsistence beef \\
Total number of respondents & - & 20 & 25 \\
Proportion of women & $\%$ & 15 & 64 \\
Age of respondent & years & $49.8 \pm 9.4$ & $38.8 \pm 7.39$ \\
Area reserved for forages & ha & $2.9 \pm 3.0$ & $0.28 \pm 0.11$ \\
Land tenure status: owner & $\%$ & 90 & 80 \\
Total livestock holdings & TLU & $36.8 \pm 51.7$ & $15.6 \pm 11.8$ \\
Cattle and buffalo heads & - & $28.6 \pm 47.8$ & $2.5 \pm 1.6$ \\
Market orientation (livestock) & $\%$ & 100 & 60 \\
Cash spent on seeds & USD & 40 & 9 \\
Years spent growing forages & years & $24.6 \pm 7.2$ & $8.42 \pm 4.07$ \\
Member of a farmer organization & $\%$ & 100 & 100 \\
\hline
\end{tabular}

${ }^{1}$ Average and standard deviation for quantitative variables; Proportion of total for categorical variables

2 TLU $=$ Tropical Livestock Units, calculated as follows: cattle $=0.70$, buffalo $=0.70$, sheep and goats $=0.10$, pigs $=0.20$ and chicken $=0.01$

Source: Wilson, 2003
While farmers in the Philippine site cultivated at least two different forage species, farmers in Vietnam usually maintained only one, complementing their livestock feed basket with multiple crop residues such as top leaves of sugarcane (12 farmers) and chopped banana stems (five farmers).

\section{Seed Exchange Networks}

\section{Network Properties}

Forage seed networks constructed from the survey data comprised 30 nodes with 74 exchanges in the Philippines and

Table 3 Forage species used in the two locations

\begin{tabular}{|c|c|c|c|c|c|}
\hline \multirow[t]{2}{*}{ Type } & \multirow[t]{2}{*}{ Common name / variety } & \multirow[t]{2}{*}{ Species } & \multirow[t]{2}{*}{ Native range } & \multicolumn{2}{|l|}{$\begin{array}{l}\text { Number of } \\
\text { respondents }\end{array}$} \\
\hline & & & & Philippines & Vietnam \\
\hline \multirow[t]{9}{*}{ Grasses } & Napier Pakchong 1 'Super napier' & Pennisetum hybrid & Africa; hybrid generation Thailand & 9 & 2 \\
\hline & Napier 'native' & Pennisetum purpureum & Africa & 8 & 20 \\
\hline & Stargrass & Cynodon nlemfuensis & Africa & 1 & \\
\hline & Signal grass & Brachiaria decumbens & Central/East Africa & 4 & \\
\hline & Mulato II & $\begin{array}{l}\text { Brachiaria ruziziensis } \\
\quad x B . \text { decumbens } x B . \\
\text { brizantha }\end{array}$ & Tropical Africa (var.) & 12 & 1 \\
\hline & Mombasa & Panicum maximum & Tropical Africa & 9 & 2 \\
\hline & Guinea grass & Megathyrsus maximus & Africa/middle east & 3 & \\
\hline & Guatemala grass & Tripsacum sp. & Tropical Americas & 1 & \\
\hline & African bristlegrass & Setaria sphacelate & Africa & 1 & \\
\hline \multirow[t]{6}{*}{ Legumes } & Centro / butterfly pea & Centrosema pubescens & Central/South America & 1 & \\
\hline & Forage peanut & Arachis pintoi & Brazil & 1 & \\
\hline & Stylo & Stylosanthes guianensis & Central/South America & 2 & \\
\hline & Ipil-ipil & Leucaena leucocephala & $\begin{array}{l}\text { Southern Mexico/Northern Central } \\
\text { America }\end{array}$ & 1 & \\
\hline & Kakawate & Gliricidia sepium & Pacific Central America & 1 & \\
\hline & Zollinger's indigo & Indigofera zollingeriana & Tropical/subtropical Asia & 2 & \\
\hline \multirow[t]{3}{*}{ Shrubs and trees } & Mulberry & Morus alba & Northern China and India & 1 & \\
\hline & Madre de agua & Trichanthera gigantea & Central and South America & 3 & \\
\hline & Yemane & Gmelina arborea & Mainland Southeast Asia + India & 1 & \\
\hline
\end{tabular}


Table 4 Network descriptors of forage seed networks in Vietnam and the Philippines

\begin{tabular}{llllll}
\hline & \multicolumn{2}{l}{ Philippines } & & \multicolumn{2}{l}{ Vietnam } \\
\cline { 2 - 3 } $\begin{array}{l}\text { Degree of } \\
\text { node }\end{array}$ & \# of nodes & $\begin{array}{l}\text { Frequency } \\
(\%)\end{array}$ & & \# of nodes & Frequency (\%) \\
\hline 1 & 7 & 23.3 & 9 & 19.1 \\
2 & 3 & 10.0 & 13 & 27.7 \\
3 & 4 & 13.3 & 7 & 14.9 \\
4 & 3 & 10.0 & 7 & 14.9 \\
5 & 3 & 10.0 & 4 & 8.5 \\
6 & 1 & 3.3 & 2 & 4.3 \\
7 & 4 & 13.3 & 3 & 6.4 \\
8 & 2 & 6.7 & 0 & 0.0 \\
9 & 1 & 3.3 & 0 & 0.0 \\
10 & 0 & 0.0 & 1 & 2.1 \\
11 & 0 & 0.0 & 1 & 2.1 \\
15 & 1 & 3.3 & & \\
22 & 1 & 3.3 & & \\
\hline
\end{tabular}

47 nodes with 79 recorded exchanges in Vietnam. Multiple exchanges between the same pairs of nodes were aggregated in each network. Table 4 presents the basic properties of the node degree distribution from each case study. The Philippine network included many nodes with medium degrees and several nodes with very high degrees. At the same time, in Vietnam, the distribution was less concentrated in more significant numbers of nodes with lower degrees. The majority of varieties in both cases originally entered the network via formal institutions.

The forage seed exchange networks for the Philippines and Vietnam are visualized in Figs. 2 and 3, respectively, weighted in each case by in-degree centrality, out-degree centrality, overall degree centrality, and betweenness centrality. The supplementary materials provide detailed tables of computed values for each case (tables SM1 and SM2).

In the Philippines, five of the interviewed farmers occupied nodal positions with relatively higher measures of degree centrality (7-8) compared to the computed average (4.7), while institutions like the NDA, Philippines New Zealand project, and UPLB-DTRI had high values indicating central importance (20, 15, and 9, respectively) (Fig. 2C). The maximum in-degree score of 6 (average in-degree of 2.46), was held by a farmer, who frequently accessed both formal (government institutions and NGO), and informal (cooperative members and peripheral farmers) seed sources. Individual farmers from SAMBACO and PALCON were essential links to groups of farmers in the network's periphery, increasing seed dissemination from the network core (Fig. 2A). The primary seed source to farmers in all cooperatives was a central government institution, the NDA, with the highest out-degree score of 18 (average $=2.46$ ). The NDA and the closely-linked Philippines New Zealand Dairy Project are essential suppliers of diversity, introducing and conducting first-level distribution of improved forage seed originating in Thailand and elsewhere in the Philippines (Fig. 2B). The NDA also plays a critical role in bridging otherwise not closely connected nodes, with a network betweenness score of 39.7. Four farmers acted as important connector nodes, with betweenness scores of 16, 7.65, 6.1, and 5.45 (Fig. 2D). The survey results indicate that these gatekeeper farmers were the leaders of cooperatives, board members, and a 'best farmer' awardee.

In the Vietnamese case, 16 nodes were identified as nodal and connector actors (Fig. 3C): 11 individuals and five institutional actors. Actors had on average 3.34 connections to other nodes (average centrality score). Nodal and/or connector actors identified were farmers, traders, and government institutions. The highest in-degree score in the network (8) was the Mai Son Agriculture Service Center (ASC). This local government institution has direct access to diverse sources of seeds through government institutions (Fig. 3A). The Agriculture Service Center (ASC) had the second-highest betweenness centrality score and played a central role in supporting and deploying local and central government livestock and veterinary services programs.

The highest out-degree scores were 5 and 6, representing a communal union, a local trader, and Ubon Forage Seeds (Fig. 3B), a private seed supplier from Thailand, necessary for introducing new varieties. A local trader occupied an essential central position in the network, providing products and services related to livestock production in Chieng Chung commune, with a betweenness centrality score of 155 (Fig. 3D). Communal veterinarians also appeared in the network, taking on roles in seed distribution in addition to their work on vaccination programs and local veterinary services. Node s2 was a vital connector, without whom the network would appear fragmented. Nodes s13, s17, s20,s25, s27, and s32 were local traders playing essential roles in providing and delivering forage seed. Finally, node s1 was a retired extension officer in Chieng Luong commune, with a strong local influence and much experience with forage introduction.

The distribution of the seed exchange network parameters differed between the two cases (Fig. 4). Compared to the Philippines, where the network had two dominant nodes, the distribution of the degree centrality scores in Vietnam was flatter, with greater evenness between a higher number of nodes. This difference was also apparent in betweenness centrality. At the same time, one leading government actor had a significant connecting role in the Philippines; at least six main actors shared this role in Vietnam, backed up by a range of actors with medium influence. 

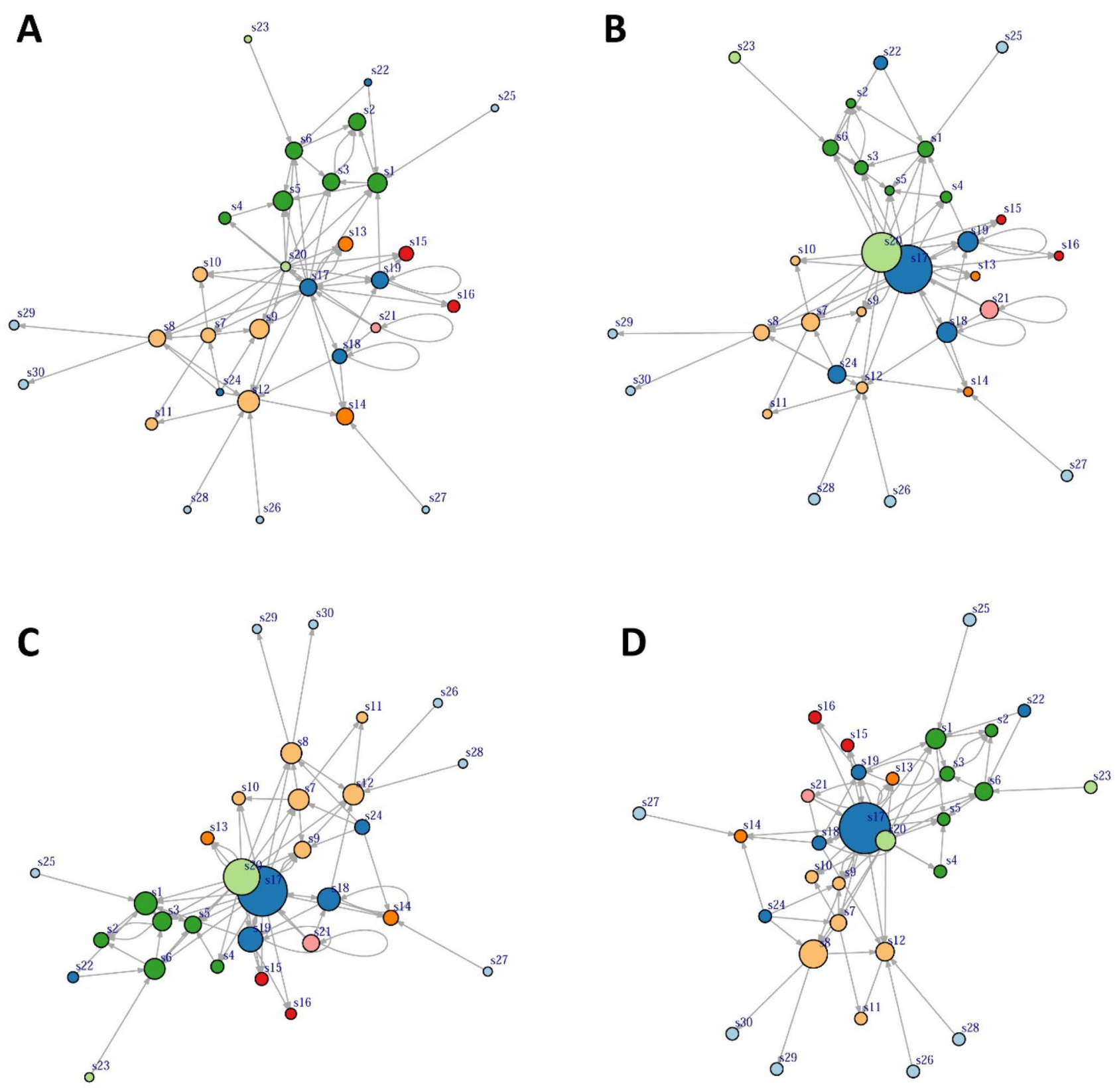

Friend $\quad \square \quad$ NGO

Private

SAMABACO

Government

PALCON

Fig. 2 Forage seed exchange network in the communities of Philippines: (A) in-degree centrality, (B) out-degree centrality, $(\mathbf{C})$ degree centrality and (D) betweenness centrality. Node size indicates relative degree centrality and betweenness centrality score and node color

\section{Types of Seed Transactions and Seed Sources}

Interviewed farmers clearly remembered when and whom they obtained seed from, but in some cases had trouble recalling whom they gave it to, perhaps due to the often

represents actor type (interviewed farmers are categorized based on their cooperative membership: PALCON, SALBA, SAMABACO or SAPADACO). Self-loops indicate self supply or gathering from communal areas

opportunistic and informal nature of seed requests or the higher social cost of requesting compared to providing seed.

In the Philippines case, free seed distribution by the government and NGOs was the most common way of obtaining seeds in the last five years, followed by gifts, 

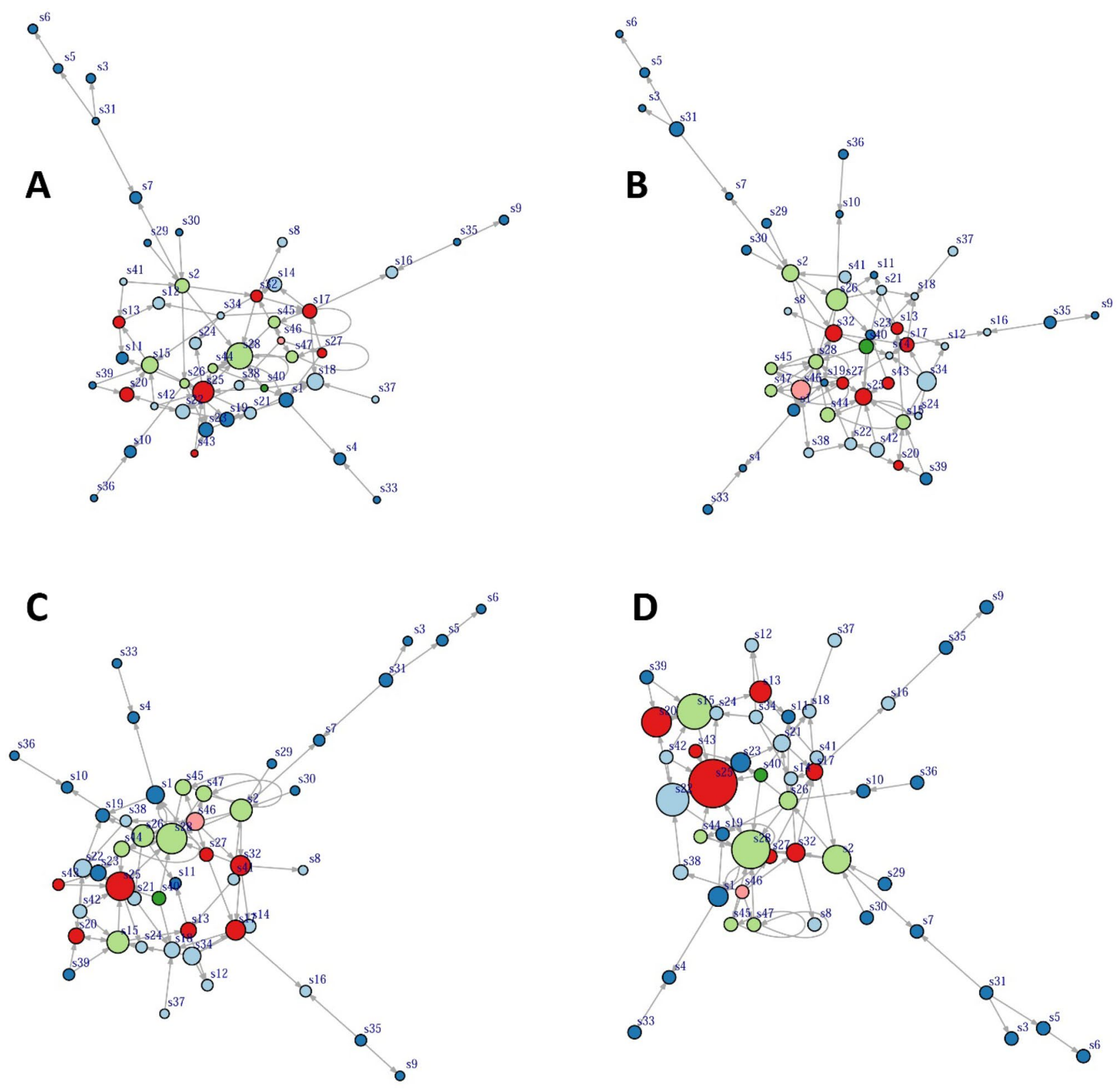

Trader

Fig. 3 Forage seed exchange network in the communities of Vietnam: (A) in-degree centrality, (B) out-degree centrality, $(\mathbf{C})$ degree centrality and (D) betweenness centrality. Node size indicates rela-

with $43 \%$ and $33 \%$ of the transactions, respectively (Table 5). In the Vietnam case, gifts dominated the transactions $(53 \%)$, followed by purchases with $27 \%$. Seed distribution in Vietnam only accounted for $16 \%$ of the observed transactions. The gathering of native forage tive degree centrality and betweenness centrality score and node color represents actor type (interviewed farmers are categorized based on their communal organization: Chieng Chung or Chieng Luong)

species was uncommon, accounting for no more than $10 \%$ of the transactions in each site.

Transactions involved different types of social relations between the seed provider and the recipient (Table 6). In the Philippines case, government institutions and NGOs were 
Fig. 4 Distribution of the seed exchange network parameters in the Philippines and the Vietnam cases. Two outliers are omitted for readability purposes in the betweenness centrality graph for Vietnam (scores 111 and 156)
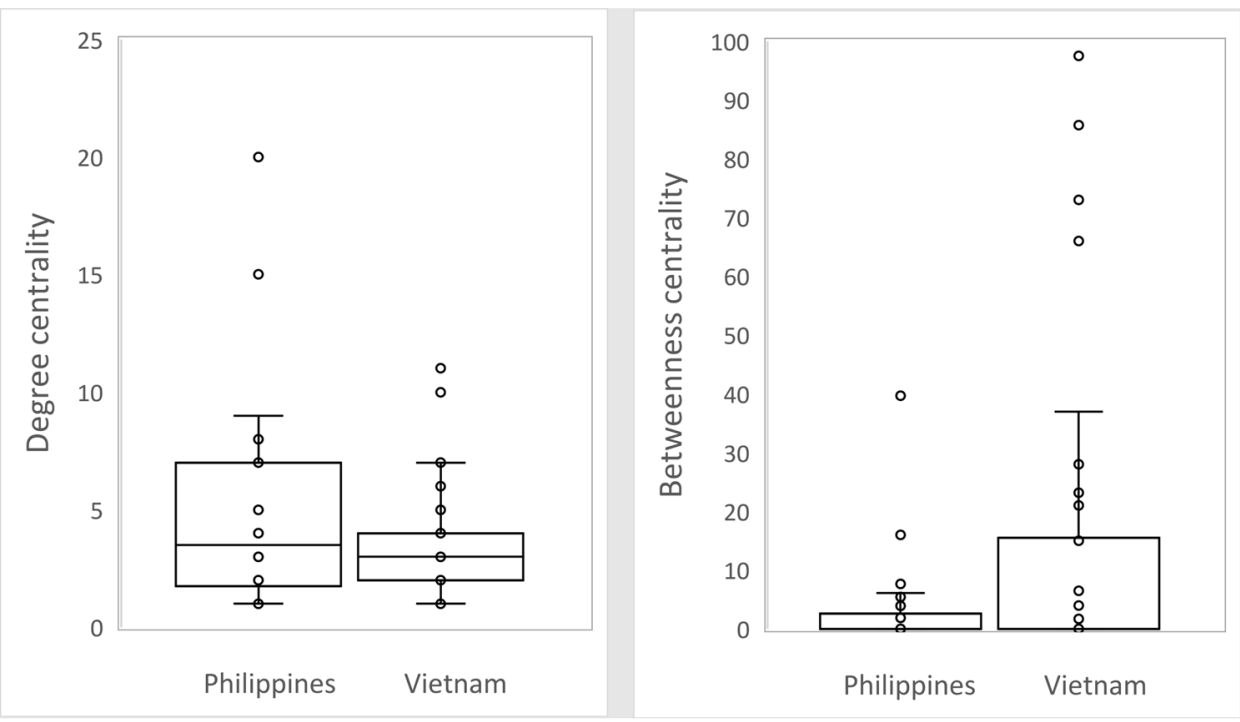

the most critical seed providers (63\%), followed by cooperative members (26\%). Family, neighbors and traders were not involved in transactions (or were already accounted for as fellow cooperative members). Different types of social relationships were involved in Vietnam, with equal importance of the government and neighbors and family combined, which were involved in $30 \%$ and $28 \%$ of the transactions, respectively. There was no formal cooperative, but friends and communal groups made up $19 \%$ of the transactions. Traders were involved in $14 \%$ of Vietnamese transactions, an actor type wholly absent in the Philippines case.

Each type of actor was involved in different transactions in both sites (data not shown). Native material was gathered primarily by government actors, cooperatives, and farmers themselves. Gifts were prevalent among friends (27\%), followed by family, neighbors, and cooperatives. The government was also implicated in $12 \%$ of gift transactions, although these transactions may have been better attributed to the seed distribution category. Official seed distribution, a more formal way of cost-free dissemination, was attributed to the government $(67 \%)$, NGOs, and cooperatives.

Interestingly, purchases did not exclusively involve traders and private enterprises ( $42 \%$ in total) but also government and NGO actors. Government actors in both sites were involved in different business and extension models, with and without payment, and participated in germplasm collection and seed production ( $42 \%$ of the gathered category). Cooperative members also produced their planting materials, mainly through vegetative means.

Regarding information sources, government institutions were the most trusted actors, together with close relatives, i.e., family, friends, and cooperative members. The most common way of obtaining information about seed varieties was through conversations among close relatives and field observations.

\section{Flows of Planting Material}

Figure 5 illustrates the transaction networks at both sites. In the Philippines case, seeds were distributed primarily by government and NGO actors to the members of the cooperatives, while farmer to farmer exchange was typically for vegetative material. Multiple flows of plant materials were observed between government and private enterprises. Similar trends were observed in the Vietnam site, with government actors and traders playing essential roles in
Table 5 Types and number of seed transactions in the two locations

\begin{tabular}{|c|c|c|c|c|c|}
\hline \multirow[t]{2}{*}{ Type of transaction } & \multirow[t]{2}{*}{ Description } & \multicolumn{2}{|c|}{ PH Transactions } & \multicolumn{2}{|c|}{ VN Transactions } \\
\hline & & $\#$ & $\%$ & $\#$ & $\%$ \\
\hline Gathered & $\begin{array}{l}\text { Naturally found in the surroundings or } \\
\text { self-produced }\end{array}$ & 13 & 10 & 6 & 4 \\
\hline Gift & Non-financial transaction & 43 & 33 & 84 & 53 \\
\hline Purchase & Bought in exchange for money & 17 & 13 & 42 & 27 \\
\hline Seed distribution & $\begin{array}{l}\text { Distributed for free, often by government } \\
\text { and NGOs }\end{array}$ & 56 & 43 & 26 & 16 \\
\hline Total & & 129 & & 158 & \\
\hline
\end{tabular}


Table 6 Transactions by type of seed provider in the two locations

\begin{tabular}{|c|c|c|c|c|c|c|c|}
\hline \multirow[t]{2}{*}{ Social relations } & \multirow[t]{2}{*}{ Description } & \multicolumn{2}{|c|}{ PH Transactions } & \multicolumn{2}{|c|}{ VN Transactions } & \multicolumn{2}{|c|}{ Total } \\
\hline & & \# & $\%$ & \# & $\%$ & \# & $\%$ \\
\hline Family & Relatives as interpreted by the interviewee & - & - & 24 & 15.2 & 24 & 8.4 \\
\hline Friends/peers & $\begin{array}{l}\text { Workmates and people who belong to the same social } \\
\text { organizations, church group, or communal work group }\end{array}$ & 5 & 3.9 & 30 & 19.0 & 35 & 12.2 \\
\hline Government & National and local government institutions & 54 & 41.8 & 52 & 32.9 & 106 & 36.9 \\
\hline Neighbour & Neighbours that live in the same community & - & - & 20 & 12.7 & 20 & 7.0 \\
\hline Trader & Seed traders in the community & - & - & 22 & 13.9 & 22 & 7.7 \\
\hline Cooperative & People that belong to the same community cooperative & 33 & 25.6 & - & - & 33 & 11.5 \\
\hline Private & Private enterprise that provides seeds & 4 & 3.1 & - & - & 4 & 1.4 \\
\hline NGO & Non-government organizations program and projects & 28 & 21.7 & - & - & 28 & 9.7 \\
\hline Self & Forages found naturally in the community & 5 & 3.9 & 10 & 6.3 & 15 & 5.2 \\
\hline Total & & 129 & & 158 & & 287 & \\
\hline
\end{tabular}

disseminating true botanical seeds. At the same time, farmer to farmer exchanges was typical of vegetatively propagated materials. In both sites, government institutions produced planting materials for dissemination and sourced them from Ubon Forage Seeds in Thailand for improved varieties such as Mulato II and Mombasa.

\section{Discussion}

\section{Farmers, Collective Action, and Institutions in Forage Seed Exchange and Diversity}

In both Vietnam and the Philippines, exotic improved forages dominated the exchange networks, with a gathering of native species occurring in less than $10 \%$ of cases surveyed. Exchange of native species may not be seen as a priority, either due to persistence in the landscape or national programs preferring to import improved varieties from successful breeding programs abroad. The central positions of government actors in the networks of both cases were similar, but their patterns of interaction with the rest of the network differed.

In the Philippines, $100 \%$ of farmers were market-oriented in dairy cooperatives. Participation in dairy cooperatives provided a connection to active sharing networks with solid links to national institutions.

Following an initial introduction by government or NGOs, cooperative farmers or community leaders accessed seed more frequently and for a wider variety of forage species, occupying essential roles in secondary dissemination networks. Community or institutional leaders may already possess advantages in social standing, education, or affluence, enabling them to be more risk-taking and receptive
A

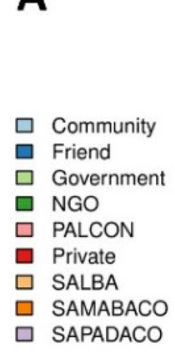

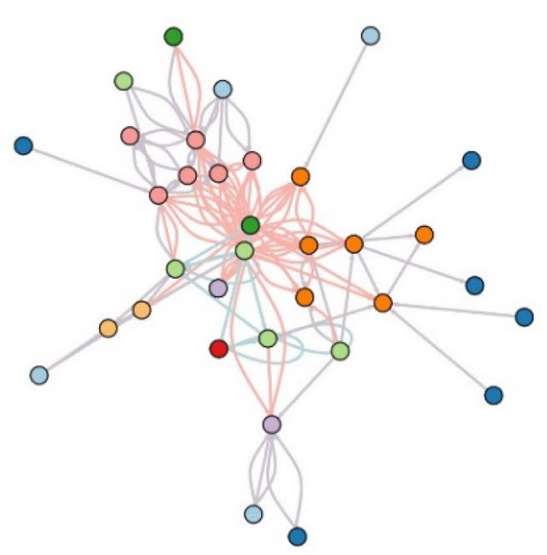

B

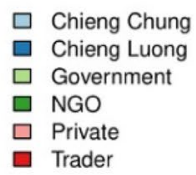

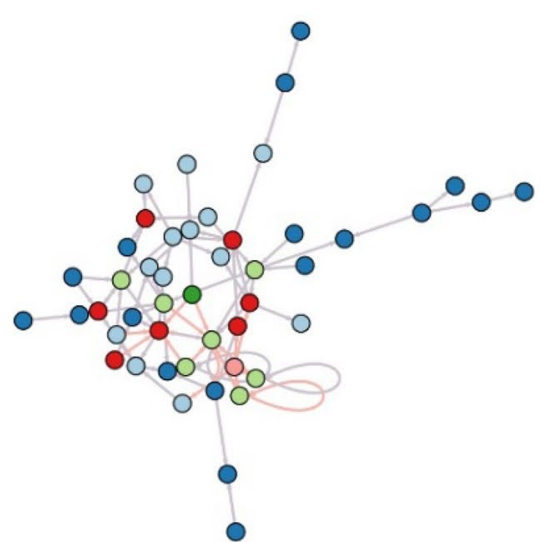

Fig. 5 Seed network flow of forage genetic materials across the different groups in the Philippines site (A) and in the Vietnam site (B). Color of the arrows represent the type of material exchange and flow: Pink $=$ Seed; Violet $=$ Vegetative; Blue $=$ Multiple $($ Seed and Vegetative $)$ 
to new technologies (Delaquis \& Almekinders, 2020); for example land and labour endowment have previously been identified as factors limiting improved forage adoption (Gebremedhin et al., 2003). Farmers with fewer heads of cattle and smaller forage areas typically only maintained one or two forage varieties, acquired from other cooperative members or gathered from community spaces. However, at both sites, the nodal farmers often played the role of 'model farmers' in their communities, engaging in onfarm testing of new forages and linking new knowledge to their communities. Most exchanges between farmers were not financial transactions, especially if the amount was minor, and NDA-provided free seed was the most common acquisition method. This model may be sustainable as long as the central institution is well-functioning and funded but could hamper the development of the commercial seed industry. Conversely, gifting of seed with no associated financial cost may also have enabled farmers to access the greater diversity of seeds they maintained, as Stromberg et al. (2010), found in the case of maize.

In Vietnam, a beef-based system with both market and subsistence components, farmers were less motivated for collective action and acquired forage materials from government actors, family members, and traders, the latter especially when enough material could not be sourced for free. Overall, forage species diversity in Vietnam was very low. As in the Philippines, government institutions such as the agriculture service center maintained important primary roles for entry of improved forages into the network, acquiring forage materials from other government institutions, colleges, and universities, and providing them for free to the farmers in the network. In both case studies, government actors played gatekeeping roles in introducing new forage species and varieties. This is unsurprising given the logistics and complexity of imports from suppliers based outside the country. Regulatory barriers have long since been identified as hurdles to developing effective seed enterprises, sometimes to such an extent that state and parastatal institutions better suited to navigate the bureaucracy often end up filling the role rather than private sector actors (e.g., Tripp, 1997b). Governments usually operate specialized institutions to improve agricultural productivity, partly through introducing and disseminating improved varieties. From this perspective, local seed systems can be conceptualized as branches of a small world network of global exchange of forage genetics. Such an approach has been adopted for mapping the networks of resistance genes in crop breeding programs (Garrett et al., 2017). The presence of international linkages through the government exchange, CGIAR hubs, and Ubon Seeds in Thailand for both case studies suggests that this level of analysis could provide relevant insights to increase access to adapted forages.
The participation of traders and veterinarians as seed suppliers was unique to Vietnam and indicates the development of adaptive network pathways for forage dissemination when collective action was less pronounced. Traders have critical roles in many informal seed systems, and calls have been made to rethink their importance in seed supply and security (e.g., Delaquis et al., 2018; Sperling et al., 2020). Despite this, the adoption of improved forage seed was not common.

\section{Market Orientation and Environmental Drivers of Seed Exchange Network Development}

Smallholder dairying is a technologically advanced activity requiring a redesign of the livestock production system and aspects of the supporting social system (Paul et al., 2019). Because of the challenges inherent in maintaining milk production and quality levels, improved forages are more likely to be introduced (and adopted) as part of the dairy farming 'system', which includes the cooperative as the exclusive buyer of the product, with an invested collective business interest in maintaining production and standards. This was apparent in the centralized structure of the cooperatives with solid links to government and actors in each cooperative encouraging adoption and multiplication of improved forages.

Topographic characteristics (strong slopes) and remoteness of the farmers in the Vietnam site induce transportation issues, low market access, weak linkages between suppliers and buyers, and a general lack of market information. This was paired with lower investment in forage seed, a high preponderance of supplemental feeding with crop residues, and a relatively dispersed forage seed exchange network. Linkages with national research institutes like the National Institute of Animal Sciences (NIAS) or universities like Tay Bac University are insufficient to compensate for private sector weaknesses. It also remains to be demonstrated whether there is a business case for dedicated seed producers in this particular context or whether a subsidy is required to adopt improved varieties when demand is low. This contrasts with the Philippines site. Due to the perishability and high shipping costs of products, the dairy collectives are necessarily located where market access and connectivity are excellent. This market environment, combined with proximity to a large consumer market in Metro Manila, incentivizes the sector's organization around functional cooperatives and creates an attractive return to investment for national development programs, thus incentivizing forage improvement programs for farmers, institutions, and government.

In Vietnam, the dominant market for local beef production represents a model less sensitive to feed quality than dairy applications (Maleko et al., 2018). Therefore, farmers may seek to maximize other metrics, such as returns to labor or overall income, favoring low-cost, low-labor, or 
low-land use strategies like free grazing and supplementing with crop residues. The high dependence on off-farm income sources in Vietnam also emphasized that the farmers in this case study were less dependent on livestock in their overall livelihoods. Such an interpretation could explain why the organizational network structure in Vietnam was flatter than in the Philippines, with government's role still central and farmer union membership important, but with weaker market orientation not providing the same incentives for collective action and benefits as the government-dairy-NGO structure in the Philippines.

Climate had a substantial impact on the livestock sector in the Vietnam site, with winter temperatures routinely $<5{ }^{\circ} \mathrm{C}$ ) hindering forage production and collection and limiting potential forage species to those exhibiting high winter hardiness. Developing forage seed exchange networks should be complemented here by further developing post-harvest conservation strategies like silage making for long-term storage and availability of quality feed throughout the year. Although there was no such climate constraint in the Philippines site, the lack of silage facility in the communities of the Philippines was still identified as a significant factor limiting farm productivity.

The policy also plays a primary external driver for seed exchange network development. According to the national dairy roadmap of the Philippines, one of the main targets of the department of agriculture is to increase the selfsufficiency level in the ready-to-drink (RTD) milk market from the present $20 \%$ to $43 \%$ (NDA, 2010). The 19 existing dairy zones are planned to be expanded, and additional areas opened up to create more rural employment and boost economic growth. This policy necessitates parallel development of access to high-quality forage materials through $\mathrm{R} \& \mathrm{D}$ projects and continued investment. In Vietnam, resolution $258 / 2008$ was accompanied by a significant increase in forages cultivated. Plans for Son La's development until 2030 include restructuring the livestock sector towards large cattle and herbivores. As was the case for the 2008 resolution, the corresponding land allocation must be planned for forage production. However, we also suggest that a policy emphasis be placed on developing the forage seed system to disseminate improved forage varieties. Consideration should include maximizing the impact of existing informal networks and exploring cost/benefit analyses for more formal approaches.

\section{Cultural Norms in Forage Sharing}

Seed sharing in agricultural communities is an important individual and community act tied to profound social and cultural norms (Almekinders et al., 2020; McGuire, 2008; Rodier \& Struik, 2018).

Qualitatively, the interviews supported the network analysis results, outlining the importance of relationships in sharing forage materials in the Philippines. In most cases, the recipient farmer described sharing as being initiated, with requests for the material being very seldom refused. When asked, the need to share was expressed as a deep ethos of the community, a social norm that has been described as an essential driver of seed exchange elsewhere (Rodier \& Struik, 2018). Forage materials were perceived as being integral to livelihood opportunities, and social norms strongly motivated sharing. Nodal farmers frequently maintained positions of importance within their groups and communities, and sharing forages was considered as part of these roles. However, recipients of seeds expressed that making repeated requests for materials would be awkward or viewed poorly. It was customary for the recipient to multiply and maintain the seed they had received and likewise share it when asked. The finding that farmers typically recalled easily from whom they had obtained seed, but not nearly as readily whom they had given seed to, echoes that of Coomes et al. (2015) and may imply some social costs in seeking seed from others.

In the Vietnamese case study context, the culture of mutual assistance remains robust in social ties between farmers and their neighbors, friends, family members, and government actors. In terms of frequency of use for seed exchange, family members were almost unanimously more important than other network actors (neighbour, friend and government), and exchange among family were frequent, viewed positively, and usually had no cost attached; a similar finding to that observed after dissemination of legume seed in Africa (Almekinders et al., 2020). This finding is not surprising given the reduced market influence and importance to the overall livelihoods of cattle rearing in the Vietnamese case.

However, seed sharing with unrelated network actors, especially traders or government actors, often limited or declined or became commercial transactions. In contrast to the informal network, government dissemination programs were viewed as being very top-down and formal in their approach. This may suggest that the organization of the collective action groups may not match the prevailing social and cultural norms around seed exchange. This condition can hamper the ability of institutions to provide seed that is acceptable to farmers (Almekinders et al., 2019).

The relative ease of sharing vegetative planting materials, which are proper to varietal type, is advantageous to exchange (Bentley et al., 2018), and is supported by the more extensive exchange observed here for vegetatively propagated species. In addition to sociocultural elements of both contexts, vegetative reproduction may also help to account for the frequent sharing among farmers, including first-time growers, without the hesitancy of being considered as 'begging,' a constraint reported in other contexts (Samberg et al., 2013). 


\section{Sustainability of the Forage Seed Supply}

Forage varieties introduced with past projects are often still found in former pilot sites. Some spill-over to nearby communities can be observed through distribution among friends, relatives, and community members. Governments often maintain collections of forage varieties, which are occasionally transferred to farmers during extension projects, but why does adoption remain so limited beyond the duration of project implementation? There are likely many contributors to this lack of sustainability, ranging from lack of knowledge of propagation techniques to lack of investment by institutions in understanding seed demand and exchange network structure. Proper seed production and dissemination were dominated by government actors when networks were assembled by planting material type. The specialized practices and knowledge involved in seed production may be barriers to wider dissemination which future projects could address.

Farmer-led forage seed production has been successful in Thailand and has a critical regional role in forage availability through Ubon Forage Seeds Company (Hare et al., 2013). This company was the source of improved forage species found in both case studies. However, to be sustainable, seed businesses must be accompanied by marketoriented, coordinated plans for production and marketing. This is impossible without understanding seed networks and farmer demand segments for seed. When poorly planned, community seed banks have proven unsustainable due to high operation costs and lack of motivation to continue once startup resource endowments are exhausted (Bishaw \& Turner, 2008; Cromwell et al., 1993). Linking forage supply to demand, as occurs in the case of dairy cooperatives providing seed to their members, is one way to motivate sustainability, whereby the providers of the seed (Government, cooperatives, and NGOs) directly or indirectly capture the benefits of their use (seed sale, increased milk revenues, taxes on sale of high-value commercial products).

\section{Conclusions}

Seed tracing studies are efficient methods for rapidly assessing and characterizing seed networks. The cases investigated in the Philippines and Vietnam differed significantly according to the structure of collective action groups and market incentives, interactions with institutions, and the cultural norms of their environments.

In both cases, government agencies served as primary sources of forage introduction, with secondary diffusion in the Philippines dairy case being dominated by active commercially invested cooperatives. In the Vietnam beef context, farmer to farmer dissemination dominated a looser group in a less intensified market setting. In both cases, formal actors dominated as sources of true seed, and farmers frequently exchanged vegetatively propagated materials. However, the overall diversity of forages was markedly higher in the Philippines case, likely due to a combination of the different forage needs of the respective products of each system and large differences in the importance of livestock activities in the overall livelihoods of farmers.

Adapting to the evolving policy goals in Southeast Asia and globally will require increased focus on developing efficient seed systems to support increasingly productive livestock sectors. Our study indicates that both the formal and the informal seed sectors will play essential roles in access to forages. The interface between these systems is an increasingly important target for study to achieve impact at scale. Trends in livestock ownership and policy goals indicate continued growing demand for high-quality forages, shaped by the particularities of each case.

Recommendations include a further study on seed demand across different contexts, improvement of technical skill in seed production for valid seeded forage species, and efforts to use the strength of institutional seed arrangements to develop incentives for more extensive networks for exchange. Critically, informal seed networks must be recognized as avenues for reaching beyond group membership and ensuring that seed networks do not weaken in the absence of project or government funding. This will require stakeholders to engage in a delicate push-pull between supply and demand issues to ensure quality seed production upstream while supporting the creation of appropriate structures and incentives for ongoing seed exchange network improvement downstream.

Supplementary Information The online version contains supplementary material available at https://doi.org/10.1007/s10745-021-00274-5.

Acknowledgements and Declarations We warmly thank the interviewees for their time and collaboration. We acknowledge the support from the National Dairy Authority (NDA), Department of Agriculture Bureau of Animal Industry (DA-BAI), and University of the Philippines Los Baños Dairy Training and Research Institute (UPLB-DTRI) for sharing farm and farmer information. JEL acknowledges the support from Albert Astillero of DA-BAI and Dan Panganiban of NDA for the assistance in conducting the survey. We are also grateful for the support of the National Institute of Animal Science (NIAS), the Sub-Department of Agriculture and Rural Development, the Sub-Department of Animal Husbandry, Veterinary and Aquaculture Son La, and the Agricultural Service Center of Mai Son, Son La province, Vietnam.

This work was funded by the CGIAR Research Program on Livestock, which is carried out with support from the CGIAR Fund Donors and bilateral funding agreements.

Open Access This article is licensed under a Creative Commons Attribution 4.0 International License, which permits use, sharing, adaptation, distribution and reproduction in any medium or format, as long as you give appropriate credit to the original author(s) and the source, provide a link to the Creative Commons licence, and indicate if changes 
were made. The images or other third party material in this article are included in the article's Creative Commons licence, unless indicated otherwise in a credit line to the material. If material is not included in the article's Creative Commons licence and your intended use is not permitted by statutory regulation or exceeds the permitted use, you will need to obtain permission directly from the copyright holder. To view a copy of this licence, visit http://creativecommons.org/licenses/by/4.0/.

\section{References}

Abizaid, C., Coomes, O.T., Perrault-Archambault, M. (2016). Seed Sharing in Amazonian Indigenous Rain Forest Communities: a Social Network Analysis in three Achuar Villages, Peru. Human Ecology 44, 577-594. https://doi.org/10.1007/s10745-016-9852-7

Almekinders, C. J. M., Ronner, E., \& van Heerwaarden, J. (2020). Tracing legume seed diffusion beyond demonstration trials: An exploration of sharing mechanisms. Outlook on Agriculture, 49, 29-38. https://doi.org/10.1177/0030727020907646

Almekinders, C. J. M., Louwaars, N. P., \& de Bruijn, G. H. (1994). Local seed systems and their importance for an improved seed supply in developing countries. Euphytica, 78, 207-216. https:// doi.org/10.1007/BF00027519

Almekinders, C. J. M., Walsh, S., Jacobsen, K. S., Andrade-Piedra, J. L., McEwan, M. A., de Haan, S., Kumar, L., \& Staver, C. (2019). Why interventions in the seed systems of roots, tubers and bananas crops do not reach their full potential. Food Security, 11, 23-42. https://doi.org/10.1007/s12571-018-0874-4

Andrade-Piedra, J. L., Almekinders, C. J. M., McEwan, M. A., Kilwinger, F. B. M., Mayanja, S., Mulugo, L., Delaquis, E., Garrett, K. A., Omondi, A. B., Rajendran, S., Kumar, P. L., Thiele, G. (2020). User guide to the toolbox for working with root, tuber and banana seed systems. Lima (Peru). CGIAR Research Program on Roots, Tubers and Bananas (RTB). RTB User Guide. No.2020-1. https://doi.org/10.4160/9789290605577

Ang, P. A. (2017). Philippines Dairy and Products Annual Situation and Outlook. USDA Foreign Agricultural Service. USDA Foreign Agricultural Service. 10 December 2017

Ayele, S., Duncan, A., Larbi, A., \& Khanh, T. T. (2012). Enhancing innovation in livestock value chains through networks: Lessons from fodder innovation case studies in developing countries. Science and Public Policy, 39(3), 333-346. https://doi.org/10. 1093/scipol/scs022

Bentley, J. W., Andrade-Piedra, J., Demo, P., Dzomeku, B., Jacobsen, K., Kikulwe, E., Kromann, P., Kumar, P. L., McEwan, M., Mudege, N., Ogero, K., Okechukwu, R., Orrego, R., Ospina, B., Sperling, L., Walsh, S., \& Thiele, G. (2018). Understanding root, tuber, and banana seed systems and coordination breakdown: A multi-stakeholder framework. Journal of Crop Improvement, 32(5), 599-621. https:// doi.org/10.1080/15427528.2018.1476998

Bishaw, Z., \& Turner, M. (2008). Linking participatory plant breeding to the seed supply system. Euphytica, 163, 31-44. https://doi.org/ 10.1007/s10681-007-9572-6

Bosma, R. H., Roothaert, R. L., Asis, P., Saguinhon, J., Binh, L. H., Yen, V. H. (2003). Economic and social benefits of new forage technologies in Mindanao, Philippines and Tuyen Quang, Vietnam. CIAT Working Document No. 191

Buddenhagen, C. E., Hernandez Nopsa, J. F., Andersen, K. F., Andrade-Piedra, J., Forbes, G. A., Kromann, P., Thomas-Sharma, S., Useche, P., \& Garrett, K. A. (2017). Epidemic Network Analysis for Mitigation of Invasive Pathogens in Seed Systems: Potato in Ecuador. Phytopathology, 107(10), 1209-1218. https://doi.org/ 10.1094/phyto-03-17-0108-fi
Coomes, O. T., McGuire, S. J., Garine, E., Caillon, S., McKey, D., Demeulenaere, E., Jarvis, D., Aistara, G., Barnaud, A., Clouvel, P., Emperaire, L., Louafi, S., Martin, P., Massol, F., Pautasso, M., Violon, C., \& Wencélius, J. (2015). Farmer seed networks make a limited contribution to agriculture? Four common misconceptions. Food Policy, 56, 41-50. https://doi.org/10.1016/j.foodpol. 2015.07.008

Cromwell E., Wiggins S., Wentzel S. (1993). Sowing beyond the state: NGOs and seed supply in developing countries. Overseas Development Institute, London, UK

Csardi G., Nepusz T. (2006). "The igraph software package for complex network research.” InterJournal, Complex Systems, 1695. http:// igraph.org

Delaquis, E., Andersen, K. F., Minato, N., Cu, T. T. L., Karssenberg, M. E., Sok, S., Wyckhuys, K. A. G., Newby, J. C., Burra, D. D., Srean, P., Phirun, I., Le, N. D., Pham, N. T., Garrett, K. A., Almekinders, C. J. M., Struik, P. C., \& de Haan, S. (2018). Raising the Stakes: Cassava Seed Networks at Multiple Scales in Cambodia and Vietnam. Frontiers in Sustainable Food Systems, 2, 73. https://doi.org/ 10.3389/fsufs.2018.00073

Delaquis, E., \& Almekinders, C. J. M. (2020). COVID-19, seed security and social differentiation: When it rains, it pours. Food Chain, 9, 103-106. https://doi.org/10.3362/2046-1887.20-00003

David, S., \& Sperling, L. (1999). Improving technology delivery mechanisms: Lessons from bean seed systems research in eastern and central Africa. Agriculture and Human Values, 16, 381-388. https://doi.org/10.1023/A:1007603902380

Dinh, T. (2020). Innovations in Chieng Luong. http://www.baosonla. org.vn/vi/bai-viet/khoi-sac-chieng-luong-29692 . Accessed October 10th, 2020

Elbasha, E., Thornton, P. K., Tarawali, G. (1999). An ex post economic impact assessment of planted forages in West Africa. ILRI Impact Assessment Series 2, ILRI, Nairobi, Kenya

Gaffney, J., Anderson, J., Franks, C., Collinson, S., MacRobert, J., Woldemariam, W., \& Albertsen, M. (2016). Robust seed systems, emerging technologies, and hybrid crops for Africa. Global Food Security, 9, 36-44. https://doi.org/10.1016/j.gfs.2016.06.001

Garrett, K. A., Alcalá-Briseño, R. I., Andersen, K. F., Buddenhagen, C. E., Choudhury, R. A., Fulton, J. C., Hernandez Nopsa, J. F., Poudel, R., \& Xing, Y. (2018). Network Analysis: A Systems Framework to Address Grand Challenges in Plant Pathology. Annual Review of Phytopathology, 56, 559-580. https://doi.org/ 10.1146/annurev-phyto-080516-035326

Garrett, K. A., Andersen, K. F., Asche, F., Bowden, R. L., Forbes, G. A., Kulakow, P. A., \& Zhou, B. (2017). Resistance Genes in Global Crop Breeding Networks. Phytopathology, 107, 12681278. https://doi.org/10.1094/phyto-03-17-0082-fi

Gebremedhin, B., Ahmed, M. M., \& Ehui, S. K. (2003). Determinants of adoption of improved forage technologies in crop-livestock mixed systems: Evidence from the highlands of Ethiopia. Tropical Grasslands, 37, 262-273.

Gill, T., Bates, R., Bicksler, A., Burnette, R., Ricciardi, V., \& Yoder, L. (2013). Strengthening Informal Seed Systems to Enhance Food Security in Southeast Asia. Journal of Agriculture Food Systems and Community Development, 3(3), 139-153. https://doi.org/10. 5304/jafscd.2013.033.005

Gitaitis, R., \& Walcott, R. (2007). The Epidemiology and Management of Seedborne Bacterial Diseases. Annual Review of Phytopathology, 45, 371-397. https://doi.org/10.1146/annurev.phyto. 45.062806.094321

Hare, M. D., Phengphet, S., Songsiri, T., Sutin, N., Vernon, E. S., Stern, E. (2013). Impact of tropical forage seed development in villages in Thailand and Laos: Research to village farmer production to seed export. Tropical Grasslands 1, 207-211. https://doi.org/10. 17138/tgft(1)207-211 
Herrero, M., Thornton, P. K., Notenbaert, A. M., Wood, S., Msangi, S., Freeman, H. A., Bossio, D., Dixon, J., Peters, M., van de Steeg, J., Lynam, J., Parthasarathy Rao, P., Macmillan, S., Gerard, B., McDermott, J., Seré, C., \& Rosegrant, M. (2010). Smart Investments in Sustainable Food Production: Revisiting Mixed CropLivestock Systems. Science, 327, 822-825. https://doi.org/10. 1126/science. 1183725

Jacobsen, K., Omondi, B. A., Almekinders, C., Alvarez, E., Blomme, G., Dita, M., Iskra-Caruana, M.-L., Ocimati, W., Tinzaara, W., Kumar, P. L., \& Staver, C. (2019). Seed degeneration of banana planting materials: Strategies for improved farmer access to healthy seed. Plant Pathology, 68, 207-228. https://doi.org/10. 1111/ppa.12958

Kilwinger, F. B. M., Buddenhagen, C. E. (2021). User guide to seed tracing. Lima (Peru). CGIAR Research Program on Roots, Tubers and Bananas (RTB). RTB User Guide. No. 2021-1. https://doi.org/ 10.4160/9789290605744

Leeuwis, C., Cieslik, K. J., Aarts, M. N. C., Dewulf, A. R. P. J., Ludwig, F., Werners, S. E., Struik, P. C. (2018). Reflections on the potential of virtual citizen science platforms to address collective action challenges: Lessons and implications for future research. NJAS Wageningen Journal of Life Sciences 86-87, 146-157. 10/ggdrfh

Louwaars, N. P., \& de Boef, W. S. (2012). Integrated Seed Sector Development in Africa: A Conceptual Framework for Creating Coherence Between Practices, Programs, and Policies. Journal of Crop Improvement, 26, 39-59. https://doi.org/10.1080/15427528.2011. 611277

Maleko, D., Msalya, G., Mwilawa, A., Pasape, L., \& Mtei, K. (2018). Smallholder dairy cattle feeding technologies and practices in Tanzania: Failures, successes, challenges and prospects for sustainability. International Journal of Agricultural Sustainability, 16, 201-213. https://doi.org/10.1080/14735903.2018.1440474

McGuire, S. J. (2008). Securing access to seed: Social relations and sorghum seed exchange in eastern Ethiopia. Human Ecology., 36(2), 217-229. https://doi.org/10.1007/s10745-007-9143-4

McGuire, S., \& Sperling, L. (2013). Making seed systems more resilient to stress. Global Environmental Change, 23, 644-653. https://doi. org/10.1016/j.gloenvcha.2013.02.001

McGuire, S., \& Sperling, L. (2016). Seed systems smallholder farmers use. Food Security, 8, 179-195. https://doi.org/10.1007/ s12571-015-0528-8

McQuaid, C. F., Sseruwagi, P., Pariyo, A., \& van den Bosch, F. (2016). Cassava brown streak disease and the sustainability of a clean seed system. Plant Pathology, 65, 299-309. https://doi.org/10.1111/ppa. 12453

National Dairy Authority. (2010). The Dairy Road Map 2010-2016: A Medium-Term Dairy Development Plan. National Dairy Authority Philippines. 12 November 2010.

Paul, B. K., Groot, J. C. J., Birnholz, C. A., Nzogela, B., Notenbaert, A., Woyessa, K., Sommer, R., Nijbroek, R., Tittonell, P. (2019). Reducing agro-environmental trade-offs through sustainable livestock intensification across smallholder systems in Northern Tanzania. International Journal of Agricultural Sustainability 1-20 https:// doi.org/10.1080/14735903.2019.1695348

Pautasso, M., Aistara, G., Barnaud, A., Caillon, S., Clouvel, P., Coomes, O. T., Delêtre, M., Demeulenaere, E., De Santis, P., Döring, T., Eloy, L., Emperaire, L., Garine, E., Goldringer, I., Jarvis, D., Joly, H. I., Leclerc, C., Louafi, S., Martin, P., ... Tramontini, S. (2013). Seed exchange networks for agrobiodiversity conservation. A Review. Agronomy for Sustainable Development, 33, 151-175. https://doi. org/10.1007/s13593-012-0089-6

Phaikaew, C., Stür, W. (1998). Forage Seed Production and Seed Supply Systems in Southeast Asia, in: Meeting of the Regional Working Group on Grazing and Feed Resources for Southeast Asia (6, Legaspi, Philippines). Integrated Crop-Livestock Production Pystems and Fodder Trees: Proceedings. Food and Agriculture Organization of the United Nations (FAO); Bureau of Animal Industry (BAI), Department of Agriculture, Legaspi, Philippines, 117-124.

Philippine Statistics Authority. (2016). Dairy Industry Performance Report, January-December 2015. Quezon City: Philippine Statistics Authority, May 2016. Print.

Philp, J. N. M., Vance, W., Bell, R. W., et al. (2019). Forage options to sustainably intensify smallholder farming systems on tropical sandy soils. A Review. Agronomy for Sustainable Development, 39, 30. https://doi.org/10.1007/s13593-019-0576-0

Poudel, D., Sthapit, B., Shrestha, P. (2015). An analysis of social seed network and its contribution to on-farm conservation of crop genetic diversity in Nepal. International Journal of Biodiversity 2015, 13pp. https://doi.org/10.1155/2015/312621

Rao, I., Peters, M., Castro, A., Schultze-Kraft, R., White, D., Fisher, M., Miles, J., Lascano, C., Blümmel, M., Bungenstab, D., Tapasco, J., Hyman, G., Bolliger, A., Paul, B., van der Hoek, R., Maas, B., Tiemann, T., Cuchillo, M., Douxchamps, S., Villanuevas, C., Rincon, A., Ayarza, M., Rosenstock, T., Subbarao, G., Arango, J., Cardoso, J., Worthington, M., Chirinda, N., Notenbaert, A., Jenet, A., Schmidt, A., Vivas, N., Lefroy, R., Fahrney, K., Guimaraes, E., Tohme, J., Cook, S., Herrero, M., Chocon, M., Searchinger, T., Rudel, T. (2015). LivestockPlus - The sustainable intensification of forage-based agricultural systems to improve livelihoods and ecosystem services in the tropics. Tropical Grasslands 3, 59-82. https:// doi.org/10.17138/tgft(3)59-82

Rodier, C., \& Struik, P. (2018). Nodal Farmers' Motivations for Exchanging Sorghum Seeds in Northwestern Ethiopia. Sustainability, 10, 3708. https://doi.org/10.3390/su10103708

Roothaert, R. L., Horne, P., \& Stür., W. W. (2003). Integrating forage technologies on smallholder farms in the upland tropics. Tropical Grasslands, 37(4), 295-303.

Samberg, L. H., Shennan, C., \& Zavaleta, E. (2013). Farmer seed exchange and crop diversity in a changing agricultural landscape in the southern highlands of Ethiopia. Human Ecology, 41, 477-485. https://doi.org/10.1007/s10745-013-9579-7

Shaw, M. W., \& Pautasso, M. (2014). Networks and Plant Disease Management: Concepts and Applications. Annual Review of Phytopathology, 52, 477-493. https://doi.org/10.1146/annurev-phyto-102313-050229

Schultze-Kraft, R., \& Peters, M. (1997). Tropical legumes in agricultural production and resource management: An overview. Giessener Beiträge Zur Entwicklungsforschung No., 24, 1-17.

Scott, J. (2004). Social Network Analysis: A Handbook. Sage Publications.

Sperling, L., Gallagher, P., McGuire, S., March, J., \& Templer, N. (2020). Informal Seed Traders: The Backbone of Seed Business and African Smallholder Seed Supply. Sustainability, 12, 7074. https://doi.org/10.3390/su12177074

Stromberg, P. M., Pascual, U., Bellon, M. R. (2010). Seed Systems and Farmers' Seed Choices: The Case of Maizein the Peruvian Amazon. Hum Ecol 38, 539-553. https://doi.org/10.1007/s10745-010-9333-3

Stür, W. W., Horne, P. M., Gabunada, F. A., Jr., Phengsavanh, P., \& Kerridge, P. C. (2002). Forage options for smallholder crop-animal systems in Southeast Asia: Working with farmers to find solutions. Agricultural Systems, 71, 75-98. https://doi.org/10.1016/S0308521X(01)00037-3

Stür, W., Phengsavanh, P., Gabunada Junior, F. A., Horne, P., Khanh, T. T., Phimphachanhvongsod, V., Holmann, F. J. (2006). A survey of adoption of improved forages in Southeast Asia

Sub-Department of Agriculture and Rural Development Mai Son, Mai Son. (2018). Về việc Ban hành chính sách hỗ trợ phát triển chăn nuôi đại gia súc trên địa bàn tỉnh Sơn La giai đoạn 2009 - 2015. https:// congbao.sonla.gov.vn/congbao.nsf/32d30135c90afc13472577970 041e2eb/ebe49afeb0ae85c747257c52000fec89? OpenDocument. Accessed 15th December 2020

Tadesse, Y., Almekinders , C. J. M., Griffin, D., Struik, P. C. (2019). Collective Production and Marketing of Quality Potato Seed: Experiences from Two Cooperatives in Chencha Ethiopia. Forum for 
Development Studies 1-18 https://doi.org/10.1080/08039410.2019. 1635523

Tadesse, Y., Almekinders, C. J. M., Schulte, R. P. O., \& Struik, P. C. (2017). Tracing the seed: Seed diffusion of improved potato varieties through farmers' networks in Chencha, Ethiopia. Experimental Agriculture, 53, 481-496. https://doi.org/10.1017/S001447971600051X

Thomas, D., \& Sumberg, J. E. (1995). A review of the evaluation and use of tropical forage legumes in sub-Saharan Africa. Agriculture, Ecosystems \& Environment, 54, 151-163. https://doi.org/10.1016/ 0167-8809(95)00584-F

Tripp, R. (1997a). New seed and old laws: Regulatory reform and the diversification of national seed systems (p. 259). Intermediate Technology Publications; Overseas Development Institute.

Tripp, R. (1997b). The Institutional Conditions for Seed Enterprise Development. Overseas Development Institute. Working Paper 105, London.

Wasserman, S., \& Faust, K. (1994). Social Network Analysis: Methods and Applications. Cambridge University Press.
Wilson, R. T. (2003). Livestock production and farm animal genetic resources in the Usangu Wetland of the Southern Highlands of Tanzania. Livestock Research for Rural Development. Volume 15, Article \#2. Retrieved July 11, 2020, from http://www.lrrd.org/ lrrd15/1/wils151.htm

World Bank. (2018). Climbing the Ladder: Poverty Reduction and Shared Prosperity in Vietnam. World Bank. https://doi.org/10. $1596 / 29684$

World Bank. (2020a). https://datahelpdesk.worldbank.org/knowledgebase/ articles/906519-world-bank-country-and-lending-groups

World Bank. (2020b). https://blogs.worldbank.org/opendata/new-countryclassifications-income-level-2019-2020

World Bank. (2020c). http://documents1.worldbank.org/curated/fr/ 199951468843835123/pdf/107004-VIETNAMESE-WP-PUBLIC.pdf

Publisher's Note Springer Nature remains neutral with regard to jurisdictional claims in published maps and institutional affiliations. 